\title{
PROFESOR DR HAB. LESZEK KAJZER (11 VIII 1944-25 IX 2016)
}

W dniu 25 września 2016 roku odszedł od nas Leszek Kajzer, nasz przełożony, nauczyciel, współpracownik, wreszcie kolega i przyjaciel. Był on Uczonym cieszącym się wielkim autorytetem, Osobą powszechnie szanowaną, badaczem o renesansowych zainteresowaniach. Przede wszystkim był archeologiem, ale także historykiem, castellologiem, historykiem: kultury materialnej, sztuki, architektury.

Urodzony 11 sierpnia 1944 r. w Milanówku, po sześciu latach sprowadził się do Łodzi, z którą związał się niezwykle mocno, zostając prawdziwym lodzermenszem. W naszym mieście odbył całą edukację, którą ukończył w 1967 roku na Uniwersytecie Łódzkim na podstawie przygotowanej na kierunku archeologia, pod opieką naukową prof. dr hab. Konrada Jażdżewskiego, pracy magisterskiej Współczesny stan badań nad zagadnieniami ciagłości osadnictwa.

Już w trakcie studiów wyróżniał się pasją badawczą. Na ostatnim roku zdecydowanie zaczęło przeważać zainteresowanie problematyką budownictwa obronnego. Dzięki temu od razu po magisterium został zaangażowany w Zakładzie Archeologii Polski Środkowej Instytutu Historii Kultury Materialnej PAN, w Pracowni Historii Dawnego Uzbrojenia, której kierownikiem był prof. dr hab. Andrzej Nadolski. W Polskiej Akademii Nauk w 1973 r. obronił doktorat Uzbrojenie i ubiór rycerski w średniowiecznej Małopolsce w świetle źródet ikonograficznych.

W 1978 roku Leszek Kajzer przeniósł się do Katedry Archeologii Uniwersytetu Łódzkiego, gdzie rozwijał swą karierę naukową. W 1980 r. na podstawie wysoko ocenionej rozprawy Studia nad świeckim budownictwem obronnym województwa łęczyckiego w XIII-XVII wieku uzyskał stopień doktora habilitowanego, zaś w 1991 r. otrzymał tytuł profesora.

Po zatrudnieniu na uczelni jedną z pasji Profesora stała się dydaktyka. Dokonania na tym polu należy podzielić na kilka grup. Do pierwszej z nich trzeba 
zaliczyć bezpośrednią pracę $\mathrm{z}$ adeptami archeologii poprzez prowadzenie ćwiczeń, konwersatoriów, wykładów, proseminariów i seminariów. Były to zajęcia, co i dzisiaj, niestety, nie jest normą ,interaktywne”, zmuszające uczestników, nie tylko do bezkrytycznego prezentowania nabytej samodzielnie wiedzy, ale do myślenia, formułowania swoich opinii i właściwego kojarzenia faktów.

Oprócz zajęć będących już w kanonie programu studiów, takich jak: proseminaria, wstęp do muzealnictwa, praktyki muzealne, ćwiczenia z archeologii wczesnośredniowiecznej, historia archeologii, czy wykłady monograficzne (m.in: Kultura Europy późnośredniowiecznej, czy Kościół w kulturze średniowie$c z a$ ), wprowadził nowatorskie zajęcia z pionierskiej dziedziny, która pasjonowała Profesora i którą umieścił w programie nauczania akademickiego, czyli archeologii historycznej. Niewątpliwie był to ważny przełom, nie tylko dla środowiska łódzkiego. Pierwsze z tych wykładów były zatytułowane: Wybrane zagadnienia $z$ archeologii średniowiecznej $i$ nowożytnej i stanowiły wyjście archeologii akademickiej poza ramy chronologiczne wczesnego średniowiecza. Cykl ten został zakończony wraz z pojawieniem się nowych zajęć w ramach bloku Archeologia powszechna z podtytułem Późne średniowiecze i nowożytność. Rozpoczęly się one w roku akademickim 1994/1995 i trwają nieprzerwanie do chwili obecnej. Kolejnym blokiem przedmiotów kierowanych przez Leszka Kajzera były zajęcia specjalizacyjne Archeologia historyczna Polski na tle porównawczym. W ich ramach Profesor osobiście prowadził cykliczne, semestralne wykłady z okresów wczesnego średniowiecza, późnego średniowiecza i nowożytności. Rozpoczęły się one w roku akademickim 1997/1998 i zakończyły wraz z zamknięciem jednolitych studiów magisterskich w roku akademickim 2009/2010. Od czasu wprowadzenia systemu bolońskiego (2007/2008) prof. Kajzer dla studentów studiów magisterskich prowadził zajęcia Archeologia historyczna (współprowadzili je także prof. Marian Głosek i prof. Anna Marciniak-Kajzer).

Innymi zajęciami bardzo ważnymi dla Leszka Kajzera - dydaktyka, i wielce pożytecznymi dla studentów, były ćwiczenia terenowe. Tam łączyły się pasje dydaktyczna z badawczą. Był to pokaz doskonałej organizacji badań od elementów najbardziej przyziemnych poprzez wykonywanie eksploracji, dokumentacji, analizy odkrytych faktów i wyciągania wniosków. Jednocześnie było to nauczanie współżycia w grupie ludzkiej i pracy zespołowej. Elementy te nie zamykały się po 6 czy 8 godzinach obowiązkowych ćwiczeń, czy 10 godzinnym dniu pracy w końcowych fazach działania ekspedycji, ale także obejmowały poznawanie okolicy, miejscowych obyczajów i niuansów, czy wreszcie wspólne wieczory przy przeciągających się do późnych godzin nocnych kolacjach, ogniskach oraz grillach. Jednocześnie Profesor bardzo dbał o to, aby badania były jak najbardziej interdyscyplinarne. Uczestnikami ekspedycji byli też m.in.: studenci historii, historii sztuki, biologii, chemii, czy architektury. Były to także, ze względu na rozległe kontakty Leszka Kajzera (którego w terenie odwie- 
dzali liczący się badacze), okazje do poznania wielu wybitnych fachowców: architektów, historyków, historyków sztuki, geografów, biologów, fizyków, budowlańców i przedstawicieli innych dyscyplin. Ćwiczenia terenowe uczyły też studentów wykorzystywania nowych możliwości i technik badawczych oraz samodzielności badawczej.

Kolejnymi, ważnymi zajęciami prowadzonymi od roku akademickiego 1983/1984, były seminaria dyplomowe: magisterskie i licencjackie (w latach 2009-2012). Były one zawsze otwarte i pozwalające studentom na rozwijanie ich indywidualnych zainteresowań. Nacisk w nich położony był na pracę własną, oczywiście pod czujnym okiem prowadzącego. $Z$ tego też powodu prof. Leszek Kajzer zawsze miał nadkomplet chętnych do udziału w tych zajęciach. Efektem jest imponująca liczba wypromowanych dyplomantów - ponad 30 licencjatów, 200 magistrów i blisko 20 doktorów.

Profesor Leszek Kajzer był także wybitnym naukowcem - praktykiem. Rolę dominującą w Jego dorobku zajmowały badania archeologiczno-architektoniczne. Prowadził liczne i długotrwałe prace terenowe obiektów architektury murowanej, zarówno o charakterze obronnym, a więc zamków, dworów obronnych, wiejskich siedzib obronnych i wszelkich innych obiektów mieszczących się w określeniu „budownictwo obronne”, jak i rezydencjonalnym, gdzie w polu zainteresowań były dwory i pałace. Kolejnym obszarem dociekań naukowych były obiekty sakralne, a więc zespoły klasztorne, klasztorno-pałacowe, czy poszczególnie świątynie. Badania na ponad 100 stanowiskach objęły swoim zakresem terytorium całej Polski, choć koncentrowały się głównie na historycznych ziemiach łęczyckiej i sieradzkiej, Sandomierszczyźnie, Kujawach i ziemi dobrzyńskiej, Pomorzu Gdańskim, Górnym Śląsku i w Małopolsce. Profesor Leszek Kajzer prowadził prace archeologiczne także na stanowiskach w wielu krajach europejskich: Wielkiej Brytanii, Danii, Hiszpanii, na Węgrzech, Czechosłowacji.

Nie można mówić o Profesorze, nie wspominając o jego imponującej twórczości naukowej. Liczba opublikowanych dzieł przekroczyła już 600 publikacji; 26 książek i wiele artykułów. Jego prace wydawane były w 15 krajach Europy i Stanach Zjednoczonych.

Wymienić tu trzeba kilka, moim zdaniem, najważniejszych. Pierwsza, to sensu stricte podręcznik akademicki do dziś aktualny i jedyny, napisany na potrzeby rozwijającej się archeologii historycznej Wstęp do badań archeologiczno-architektonicznych (Łódź 1984). Druga z nich to praca Zamki i społeczeństwo (Łódź 1993), będąca panoramą budownictwa obronnego Polski od początku państwa do schyłku Rzeczpospolitej szlacheckiej napisana z perspektywy archeologa. Do tych dwóch należy także dodać monumentalne dzieło wymyślone i zredagowane przez Leszka Kajzera Leksykon zamków polskich (Warszawa 2001), będące kompendium wiedzy castellologicznej przełomu XX i XXI w. 
Z innych pozycji wymienić trzeba opublikowaną w 2010 r. książkę Dwory $w$ Polsce. Od średniowiecza do nowożytności. Jest ona pierwszą próbą sumarycznego ujęcia tej problematyki w polskiej literaturze. Nie można ponadto nie wspomnieć o pracowitości Profesora i rzetelnym traktowaniu obowiązków badacza, co owocowało szybkim publikowaniem wyników badań.

Omawiając działalność Profesora Leszka Kajzera nie sposób również zapomnieć o Jego aktywności administracyjnej, niezbędnej dla rozwoju archeologii akademickiej. Należy tutaj powiedzieć, że był On w latach 1992-1996 kierownikiem Katedry Archeologii Uniwersytetu Łódzkiego, zaś od 1996 r. do 2008 r. dyrektorem Instytutu Archeologii Uniwersytetu Łódzkiego. Jego główną misją, poza utworzeniem Instytutu, było odzyskanie pełni praw akademickich. Zadanie to w pełni się powiodło i Instytut Archeologii uzyskał prawo doktoryzowania (od 1997) i habilitowania (2005).

Godnym wyartykułowania jest, że Profesor jako jeden z pierwszych kierowników jednostek dydaktycznych zrozumiał konieczność uzyskiwania certyfikatów potwierdzających wysoką jakość prowadzonych przez nich jednostek. Dzięki Jego staraniom archeologia jako pierwszy kierunek w Uniwersytecie Łódzkim uzyskała akredytację Uniwersyteckiej Komisji Akredytacyjnej (1999), zaś później także Polskiej Komisji Akredytacyjnej (2009).

Podsumowując blisko 50-letnią działalność naukową profesora Leszka Kajzera należy podkreślić Jego silny związek z Uniwersytetem Łódzkim. Zawsze sprawy Katedry, a później Instytutu były dla Niego priorytetowe i miały trudną do przecenienia wartość. Wielowątkowość zainteresowań naukowych (a także pozanaukowych) powodowały, że był Uczonym o wielkim autorytecie. Ceniony, nie tylko przez archeologów, ale także kolegów i współpracowników z innych dyscyplin naukowych. Bardzo lubiany przez studentów, pomimo stanowczości i surowości, za sprawiedliwość w ocenach, życzliwość i umiejętność rozwiązywania problemów najprostszymi metodami.

Myślę, że dorobek naukowy Profesora Leszka Kajzera jest doceniany i wysoko oceniany przez archeologów, nie tylko w Łodzi, ale również w Polsce i Europie. Jego szeroka wiedza, horyzonty zainteresowań powodowały, że angażował się w pracę różnych organizacji i instytutów naukowych, co owocowało członkostwem najbardziej prestiżowych towarzystw naukowych polskich i zagranicznych. Z bardzo długiej listy wymienić wypada przewodniczenie Radzie Naukowej Instytutu Archeologii i Etnologii PAN oraz członkostwo: Polskiego Komitetu Narodowego ICOMOS; Międzynarodowych korporacji badaczy zamków Castrum Bene i Castella Maris Balti$c i$; Rady Programowej Narodowego Instytutu Dziedzictwa; Komitetu Nauk Pre- i Protohistorycznych; Rady Ochrony Zabytków przy kolejnych ministrach Kultury i Dziedzictwa Narodowego, rad naukowych wielu muzeów oraz towarzystw naukowych. 
Profesor Leszek Kajzer zostawił po sobie puste miejsce, które będzie bardzo trudno wypełnić. Pozostanie z nami na zawsze jako wybitny uczony o niezwykle szerokich horyzontach, znakomity nauczyciel, zawsze będący do dyspozycji chcących się uczyć, a wreszcie wspaniały przyjaciel, otwarty dla wszystkich.

Będzie go bardzo brakowej polskiej nauce, archeologii i nam wszystkim.
Aleksander Andrzejewski
Instytut Archeologii
Uniwersytet Łódzki
ul. Narutowicza 65
90-131 Łódź
e-mail: marylka@uni.lodz.pl 